\title{
Cytogenetics and Molecular Genetic Analysis of Chimerism in Marmosets (Callithrix: Primates)
}

\author{
MONIQUE O.M. SILVA ${ }^{1}$, JORGE LUÍS A. DE ARMADA², CARLOS EDUARDO S. \\ VERONA $^{3}$, GABRIELA HELIODORO ${ }^{4}$ and DENISE M. NOGUEIRA ${ }^{2}$ \\ ${ }^{1}$ Programa de Pós-Graduação em Biologia Animal, Instituto de Ciências Biológicas e da Saúde, Universidade \\ Federal Rural do Rio de Janeiro/UFRRJ, Rodovia BR 465, Km 7, 23890-000 Seropédica, RJ, Brazil \\ ${ }^{2}$ Departamento de Genética, Instituto de Ciências Biológicas e da Saúde, Universidade Federal Rural \\ do Rio de Janeiro/UFRRJ, Rodovia BR 465, Km 7, 23890-000 Seropédica, RJ, Brazil \\ ${ }^{3}$ Instituto Brasileiro para Medicina da Conservação/Instituto Tríade, Rua Silveira \\ Lobo, 32, Caixa Postal 48, Casa Forte, 52061-030 Recife, PE, Brazil \\ ${ }^{4}$ Instituto de Pesquisas Jardim Botânico do Rio de Janeiro/JBRJ, Rua Jardim \\ Botânico, 1008, 22470-180 Jardim Botânico, RJ, Brazil
}

Manuscript received on June 29, 2017; accepted for publication on September 11, 2017

\begin{abstract}
The birth of fraternal twins is a characteristic frequently observed in callitrichids. Cytogenetic studies have demonstrated hematopoietic chimerism in marmosets with the occurrence of two cell lines $2 n=46, X X / 46, X Y$ in females and males co-twins, without phenotypic changes. Amplification by PCR have also been used to verify the presence of the $S R Y$ gene in female chimaeras. Our aim was to verify the occurrence of chimerism in Callithrix sp. individuals considered as hybrids according to their intermediate phenotypes between $C$. jacchus and C. penicillata. Blood samples from 37 Callithrix sp. individuals were collected. Hematopoietic chimerism $2 n=46, X X / 46, X Y$ was detected by cytogenetic analysis in five individuals, three males and two females. A fragment of approximately $200 \mathrm{bp}$ of the $S R Y$ gene was amplified in seven females with normal external genitalia. The percentage of $32 \%$ of chimeric individuals detected in the present study is similar to that observed for pure specimens of Callithrix. These data suggests that hybridization probably does not interfere with the occurrence of twin gestation, nor of chimerism. Although cytogenetics is the main tool to identify the two cell lineages present in cases of chimerism, the amplification of the SRY gene by PCR has proved to be more efficient to identify the $\mathrm{Y}$ chromosome in cases of chimeric female marmoset.
\end{abstract}

Key words: karyotype, $S R Y$, chimaeras, hybridization.

\section{INTRODUCTION}

The callitrichids are primates of the New World, from the order Primates, Platyrrhini infraorder and Callitrichidae family, which has seven genera:

Correspondence to: Denise Monnerat Nogueira

E-mail: denisemn@ufrrj.br
Leontopithecus, Saguinus, Cebuella, Mico, Callithrix, Callimico and Callibella (Rylands et al. 2000), being the first two commonly called Tamarins and the others, Marmosets. They are characterized by their small size and by twin pregnancy, except in the genus Callimico (Miranda Ribeiro 1912) and Callibella (Van Roosmalen and 
Van Roosmalen 2003) that have only a cub by pregnancy (Hershkovitz 1977, Haig 1999, Reis et al. 2015).

The species that comprise the genus Callithrix (Erxleben 1777), namely: C.jacchus, C. penicillata, C. aurita, C. geoffroyi, C. flaviceps and C. kuhlii have pregnancy in an average of 145 days, with deliveries twice a year (Hill 1926, Oliveira et al. 2015). In addition to twins, there have been reports of birth of single, triple and even quadruple cubs, being the last two more common in captivity and with lower rates of individual survival (Tardif et al. 1984, Sweeney et al. 2012, Ward et al. 2014). When investigating the twin pregnancy in Marmosets, Hill (1926) found that the twins were from two oocytes and that they shared a single chorion. Later, Wislocki $(1932,1939)$ analyzing the placentas of several female marmosets with twin pregnancy, confirmed the anastomosis of the blood vessels. This anastomosis is responsible for the formation of chimaera individuals, which have chromosomally different cell lines derived from embryos of different sexes (Tarkowski 1970).

In humans, the occurrence of chimerism among monochorionic dizygotic twins is rare (Dunsford et al. 1953, Nicholas et al. 1957, Redline 2003, Assaf et al. 2010, Chen et al. 2013). It is found more often in cattle (Lillie 1916, 1917, Owen 1945, Dunn et al. 1968, Padula 2005), as well as in marmosets and tamarins (Wislocki 1932, 1939, Abbott 1984, Haig 1999, Wedi et al. 2011). In cattle, the whole gestation taken is approximately 290 days and the anastomosis of the placenta blood vessels occurs around the $30^{\text {th }}$ to $40^{\text {th }}$ day of gestation (Almeida and Resende 2012). In this case, the birth of chimeric females results in the freemartinism syndrome, (Lillie 1916, Padula 2005) classified as a disorder of sexual development (DSD) (MeyersWallen 2012) responsible for intersexuality of the female co-twin with a male with consequent masculinization of her reproductive tract. Most of freemartin are hermaphrodites, having ambiguous genitalia being sterile or infertile (Herschler and Fechheimer 1967, Mcfeely et al. 1967, Dunn et al. 1968, Padula 2005). This is because, in addition to the cellular exchange via anastomosis, the passage of androgenic hormones also occurs (Dominguez et al. 1990).

Bovine chimaeras presents the karyotype $2 n=60, X X / 60, X Y$. These two cell lines can be detected by culture of the testicular tissue, bone marrow and peripheral blood lymphocytes (Ohno et al. 1962, Herschler and Fechheimer 1967, Eldridge and Blazak 1976). Furthermore, it is also possible to amplify SRY gene sequences by Polymerase Chain Reaction (PCR) (Mullis et al. 1986) to confirm the chimerism (Padula 2005).

In mammals, the $S R Y$ gene is located on the short arm of the $\mathrm{Y}$ chromosome, and it is responsible for encoding a protein that, when expressed, initiates a cascade of events that lead to gonadal differentiation. This protein induces the formation of testes that are responsible for releasing androgenic hormones that lead to phenotypic sexual differentiation in males (Sinclair et al. 1990).

In callitrichids, the placental anastomosis initiates around the $19^{\text {th }}$ day and it is complete around the $29^{\text {th }}$ (Moore et al. 1985, Haig 1999), with cases of chimerism always coming from two or more concepts (Haig 1999). Chimaera unique cubs have been found, but this result possibly comes from the placental anastomosis with a cotwin that came to death followed by reabsorption of their fetal structures by the maternal organism (Jaquish et al. 1996). This characteristic is common in female marmosets and acts as a positive feedback in response to reproductive biology of the species to ensure the survival of the other twin (Tardif et al. 1984).

The hematopoietic chimerism in marmosets was firstly detected by conventional cytogenetic studies through the lymphocyte culture from peripheral blood and tissue culture of bone marrow, spleen and thymus. Two cell lines $2 n=46, X X / 46, X Y$ 
were found in marmosets (Benirschke et al. 1962, Benirschke and Brownhill 1963, Gengozian et al. 1964, 1969).

According to the karyotype, chromosome homogeneity is observed in five species of Callithrix, except for the size and morphology of the Y chromosome (Nagamachi et al. 1997). In the White-tufted-ear marmoset, C. jacchus, this chromosome can be metacentric, submetacentric or acrocentric, but in the Black-tufted-ear marmoset, C. penicillata it is metacentric or submetacentric (Nagamachi et al. 1997).

By PCR analyzes the SRY gene on the Y chromosome of males and females marmosets were amplified followed by DNA sequencing that proved to be identical for both males and females (Moreira 2002, Sanchez-Morgado et al. 2003, Takabayashi and Katoh 2011). Most cases of marmoset chimerism were studied in C. jacchus, a world-wide species used in biomedical research, being the first primate of the New World to have its genome sequenced (Worley et al. 2014). Specific XY chromosome probes have been developed as specific markers of chimerism in marmosets, allowing the precise identification of the cell type involved (Wedi et al. 2016).

In Brazil, C. jacchus is original from the Caatinga and Atlantic Forest biomes of Northeast and C. penicillata is native from the Cerrado in the Brazilian Central-Western (Hershkovitz 1977). According to the phenotype, C. jacchus exhibit white auricular tufts, gray coats in face, black crown and a white spot in the forehead. The back is light gray with dark streaks and a grayish brown tail with white rings around it. In C. penicillata, the auricular tufts are black with blackened face with a shiny white spot in the forehead. The back is light gray with dark streaks and a black tail with white rings around it (Oliveira et al. 2015). Both species were introduced in the Southeastern Brazil where they settled and have been mating, generating hybrid descendants (Mittermeier et al. 1988, Rylands 1993, 2000, Malukiewicz et al. 2015) including with the native marmoset species of the Southeast, C. aurita (Nogueira et al. 2011).

Our goal was to use the cytogenetic and the molecular genetic analyzes by means of PCR technique to verify the occurrence of hematopoietic chimerism in captive and free-living individuals of Callithrix sp. in the State of Rio de Janeiro, Brazil.

\section{MATERIALS AND METHODS}

Blood samples were collected by puncture of the femoral vein of 37 Callithrix sp. individuals (24 males and 13 females). The species to which the individuals belong could not be confirmed due to the occurrence of intermediate phenotypes between C. jacchus and C. penicillata, probably resulting from hybridization. For this reason, we used the nomenclature Callithrix sp.

The individuals were from three localities in the State of Rio de Janeiro. Eighteen freeliving individuals were captured at the Botanical Garden of Rio de Janeiro/JBRJ (22 $57^{\circ} 22^{\circ} 59^{\prime} \mathrm{S}$ and $43^{\circ} 13.43^{\circ} 14^{\prime} \mathrm{W}$ ); nine were from The Wild Animals Screening Center/CETAS-RJ/IBAMA $\left(22^{\circ} 43^{\prime} 73^{\prime \prime S}\right.$ and $\left.43^{\circ} 42^{\prime} 28^{\prime \prime} \mathrm{W}\right)$ and ten from the municipality of Campos dos Goytacazes, kept in the vivarium of the Carlos Chagas Filho Institute of Biophysics, Federal University of Rio de Janeiro/ UFRJ.

In each animal, the coloration of the coat of the back and the head was examined, with an emphasis on the ear tufts and the characteristics of the external genitalia.

The free-living individuals were captured with Tomahawk trap (18 x $18 \times 60 \mathrm{~cm})$ and subsequently sedated with Ketamine and Midazolam (10 mg/kg, intramuscular) for biological sample collection, identification and microchip marking (Microchippartners ${ }^{\circledR} ; 12 \mathrm{~mm}$ x $2.1 \mathrm{~mm}$; $0.06 \mathrm{~g}$ ) which was inserted into the interscapular region. After the full 
recovery, the free-living individuals were returned to their proper habitat.

All the procedures performed are in accordance with the System of Authorization and Information on Biodiversity/SISBIO (Number: 20435-2) and in the case of the animals of the UFRJ Vivarium, they were all registered in the National Council of Control of Animal Experimentation/CONCEA (Number: 01200.001568/2013-87).

\section{CYTOGENETIC ANALYZES}

To obtain metaphasic chromosomes, peripheral blood lymphocyte culture was performed (Moorhead et al. 1960). The chromosomes were stained with 3\% Giemsa solution and the metaphases were analyzed under an Olympus ${ }^{\circledR}$ model CH30RF100 optical microscope, with a 100x objective.

The best metaphases were selected, photographed and the karyotype of each individual was assembled in the Adobe Photoshop ${ }^{\circledR}$ CS3 program, following the organization according to Nagamachi et al. (1997).

\section{MOLECULAR ANALYZES}

To DNA extraction from the whole blood samples we used the saline precipitation method (Miller 1988). Genomic DNA was quantified in spectrophotometry (NanoDrop ND-2000, Thermo Scientific $\left.{ }^{\circledR}\right)$.

For PCR, Forward (5 '-TAC AGG CCA TGC ACA GAG AG-3') and Reverse (5 '- CTA GCG GGT GTT CCA TTG TT-3') primers were used for amplification of a fragment of approximately $200 \mathrm{bp}$ of the SRY gene (Oliveira et al. 2010). The primer set was designed based in the $S R Y$ gene sequence of $838 \mathrm{bp}$ generated by Moreira (2002) to amplify the region which includes the deletion of $9 \mathrm{bp}$ in $C$. aurita. The PCR product was sequenced and then aligned with the Basic Local Alignement Search Tool (BLAST- blast.ncbi.nlm.nih.gov/Blast.cgi) to confirm the $S R Y$ origin of the amplified fragment considering that there are other genes as Sox 3 found on the X-chromosome of eutherian mammals (Graves 1998) that can present $50 \%$ of aminoacid similarity with the HMG box in SRY. With at least 100 sequences aligned there were significant similarity only with $S R Y$ gene sequence in many Primate species, confirming the $S R Y$ origin of the sequences amplified from the samples analyzed here. Each PCR reaction of $10 \mu \mathrm{L}$ consisted of: $1 \mathrm{X}$ Buffer solution; $3 \mathrm{mM} \mathrm{MgCl} 2 ; 0.2$ mM dNTPs; 1 $\mu \mathrm{M}$ of each primer; $1.25 \mathrm{U}$ of Taq DNA Polymerase and 10 to $20 \mathrm{ng} / \mu \mathrm{l}$ of genomic DNA. The reactions were amplified in the thermocycler ProFlex $^{T M}$ PCR System-Appllied Biosystems ${ }^{\circledR}$ ThermoFisher $\operatorname{Inc}$ ), with the following temperature cycles: initial denaturation at $94^{\circ} \mathrm{C}$ for $5 \mathrm{~min}$, followed by 30 cycles at $94^{\circ} \mathrm{C}$ for $1 \mathrm{~min}, 55^{\circ} \mathrm{C}$ for $1 \mathrm{~min}$ and $72^{\circ} \mathrm{C}$ during $1 \mathrm{~min}$, ending with a period of extension at $72^{\circ} \mathrm{C}$ for $10 \mathrm{~min}$.

PCR products were separated by electrophoresis in $5 \%$ polyacrylamide gel at $100 \mathrm{~V} / 1 \mathrm{~h}$. In each gel besides the PCR product of the samples analyzed we also included a molecular weight marker (100 pb DNA ladder), a male and female positive control and a negative control reaction with ultrapure water instead of DNA to verify occurrence of contamination of the reagents. The gel result was evaluated after staining with $0.2 \%$ silver nitrate solution and the gel image was captured using the transilluminator apparatus software (L.Pix Loccus Biotechnology (C).

\section{RESULTS}

The analyzes of morphological traits such as the presence of the white spot on the forehead characteristic of C. jacchus and C. penicillata, was present in all individuals analyzed. The coloration of the head coat and auricular tufts presented a gradation from black to white. On the back of the individuals a variation in color from light gray to 
deep brown with transverse streaks were observed. On the tail, lighter colored rings around it was present. These characteristics contributed to classify as hybrids, Callithrix sp., the individuals studied. The analyzes of the external genitalia showed to be normal for both females, with the normal labia and vulva, as for the males, with scrotum and penis.

From the 37 individuals of Callithrix sp. studied cytogenetic analyzes was successful in 20 individuals, being 5 females and 15 males (Table I). In the remaining 17, it was not possible to obtain a result by this methodology. The analyzes of the karyotypes revealed a diploid number $2 \mathrm{n}=46, \mathrm{XX}$ or $\mathrm{XY}, \mathrm{NF}=74$, being the $\mathrm{X}$ chromosome submetacentric and the $Y$ metacentric, corresponding to the morphology described for C. jacchus and C. penicillata. The hematopoietic chimerism $2 \mathrm{n}=46, \mathrm{XX} / 46, \mathrm{XY}$ was detected in five of the 20 analyzed individuals of Callithrix sp., being three males and two females (Figure 1).

Amplification of the $200 \mathrm{bp} S R Y$ gene fragment occurred in samples from 22 males of Callithrix sp. In only one sample, there was no amplification, probably due to the poor DNA quality (Table II). In the females, from the 13 studied, amplification of $S R Y$ gene fragment occurred in seven, including a female in which hematopoietic chimerism had already been detected in the cytogenetic analyzes. With respect to the other chimeric female detected by cytogenetics, we suppose that there was no amplification of the $S R Y$ gene, because of the low quality of the DNA extracted (Table II).

\section{DISCUSSION}

Hybridization in Callithrix was primarily investigated in captivity (Coimbra-Filho 1970, Coimbra-Filho and Maia 1976, Coimbra-Filho et al. 1976, Rylands 1993) being also reported in hybridization zones where Callithrix species originally occurs (Hershkovitz 1975, Rylands et al. 2000, Arnold and Meyer 2006). Since the 1950's, human intervention has been associated with the range expansion of both species (Vieira 1995, Avila-Pires 1969) and recently interbreeding of $C$. jacchus and C. penicillata in Southeastern Brazil, have been also confirmed in anthopogenic hybrid zones (Malukiewicz et al. 2015, Cezar et al. 2017).

The presence of two cell lineages $2 \mathrm{n}=46, \mathrm{XX} / 46, \mathrm{XY}$ in Callithrix, comes from the cellular exchange via placental anastomosis between heterosexual twins (Benirschke et al. 1962, Gengozian et al. 1964). The frequent occurrence of chimerism (Ardito et al. 1995, Gengozian et al. 1980) in callitrichids may be related to evolutionary aspects about their social systems (Haig 1999). In these animals, parental care depends on the father and other members of the group other than the mother, explained by the high-energy costs that the female would have for the creation of twins with two births per year (Santos and Martins 2000). According to Ross et al. (2007), the chimeric lineages could generate signs of recognition of kinship between the members of the group through the genomic and phenotypic homogeneity between the individuals. This may be one of the reasons that could explain the unusual attraction of the father by the cubs, which would favor the paternal and alloparental care in the callitrichids.

Anomalies in the external genitalia of chimaera individuals have not been reported in the cases studied so far in Callithrix. However, in a female chimaera of Leontopithecus chrysomelas $(2 \mathrm{n}=46, \mathrm{XX} / 46, \mathrm{XY})$ clitoris enlargement and constriction of the vulvar opening were described (Goldschmidt et al. 2005). In the present study, the phenotype of the external genitalia was normal in males and females with chimerism, which corroborates previous studies that described that Callithrix chimaeras are normal and fertile (Benirschke et al. 1962, Ardito et al.1995).

The detection of the chimerism occurred in $32 \%$ of the total number of sampled individuals of Callithrix sp., free-living and captive in the State of 
TABLE I

Cellular lineages of the 20 individuals of Callithrix sp., with the diploid number, the identification code, sex, site and percentage of the chimerism observed for each individual. [ ] Number of metaphases found for each cell lineage.

\begin{tabular}{|c|c|c|c|c|c|}
\hline Individual & Sex & Age & Site & Cellular Lineages & $\begin{array}{c}\% \\
\text { Chimerism }\end{array}$ \\
\hline & & & CETAS-RJ/IBAMA & & \\
\hline \multirow[t]{2}{*}{ Csp001 } & $\mathrm{M}$ & Juvenile & & $2 \mathrm{n}=46, X Y[19]$ & 0 \\
\hline & & & CETAS-RJ/IBAMA & & \\
\hline \multirow[t]{2}{*}{ Csp002 } & $\mathrm{F}$ & Adult & & $2 \mathrm{n}=46, \mathrm{XX}[5] / 46, \mathrm{XY}[2]$ & $28 \%$ \\
\hline & & & CETAS-RJ/IBAMA & & \\
\hline \multirow[t]{2}{*}{ Csp003 } & $\mathrm{M}$ & Adult & & $2 \mathrm{n}=46, X Y[10]$ & 0 \\
\hline & & & CETAS-RJ/IBAMA & & \\
\hline \multirow[t]{2}{*}{ Csp005 } & $\mathrm{F}$ & Adult & & $2 n=26, X X[14]$ & 0 \\
\hline & & & CETAS-RJ/IBAMA & & \\
\hline \multirow[t]{2}{*}{ Csp006 } & $\mathrm{F}$ & Adult & & $2 \mathrm{n}=46, X X[5] / 46, X Y[5]$ & $50 \%$ \\
\hline & & & CETAS-RJ/IBAMA & & \\
\hline \multirow[t]{2}{*}{ Csp007 } & M & Adult & & $2 n=46, X X[5]$ & 0 \\
\hline & & & CETAS-RJ/IBAMA & & \\
\hline \multirow[t]{2}{*}{ Csp008 } & $\mathrm{M}$ & Adult & & $2 \mathrm{n}=46, \mathrm{XY}[7]$ & 0 \\
\hline & & & CETAS-RJ/IBAMA & & \\
\hline Csp009 & M & Juvenile & & $2 \mathrm{n}=46, X X[20] / 46, X Y[5]$ & $80 \%$ \\
\hline Csp010 & M & Adult & JBRJ & $2 \mathrm{n}=46, X Y[50]$ & 0 \\
\hline Csp011 & M & Adult & JBRJ & $2 \mathrm{n}=46, X Y[30]$ & 0 \\
\hline Csp012 & M & Adult & JBRJ & $2 \mathrm{n}=46, X Y[15]$ & 0 \\
\hline Csp013 & M & Adult & JBRJ & $2 \mathrm{n}=46, X X[5] / 46, X Y[6]$ & $45 \%$ \\
\hline Csp014 & $\mathrm{F}$ & Adult & JBRJ & $2 n=26, X X[30]$ & 0 \\
\hline Csp016 & M & Juvenile & JBRJ & $2 \mathrm{n}=46, \mathrm{XX}[3] / 46, X Y[1]$ & $75 \%$ \\
\hline Csp017 & $\mathrm{F}$ & Adult & JBRJ & $2 n=26, X X[11]$ & 0 \\
\hline Csp021 & M & Juvenile & JBRJ & $2 \mathrm{n}=46, X Y[6]$ & 0 \\
\hline Csp022 & M & Adult & JBRJ & $2 \mathrm{n}=46, \mathrm{XY}[10]$ & 0 \\
\hline Csp024 & M & Juvenile & JBRJ & $2 \mathrm{n}=46, X Y[6]$ & 0 \\
\hline Csp025 & M & Adult & JBRJ & $2 \mathrm{n}=46, \mathrm{XY}[10]$ & 0 \\
\hline Csp040 & M & Adult & JBRJ & $2 n=46, X Y[6]$ & 0 \\
\hline
\end{tabular}

Csp= Callithrix sp.; M= Male; F= Female. 


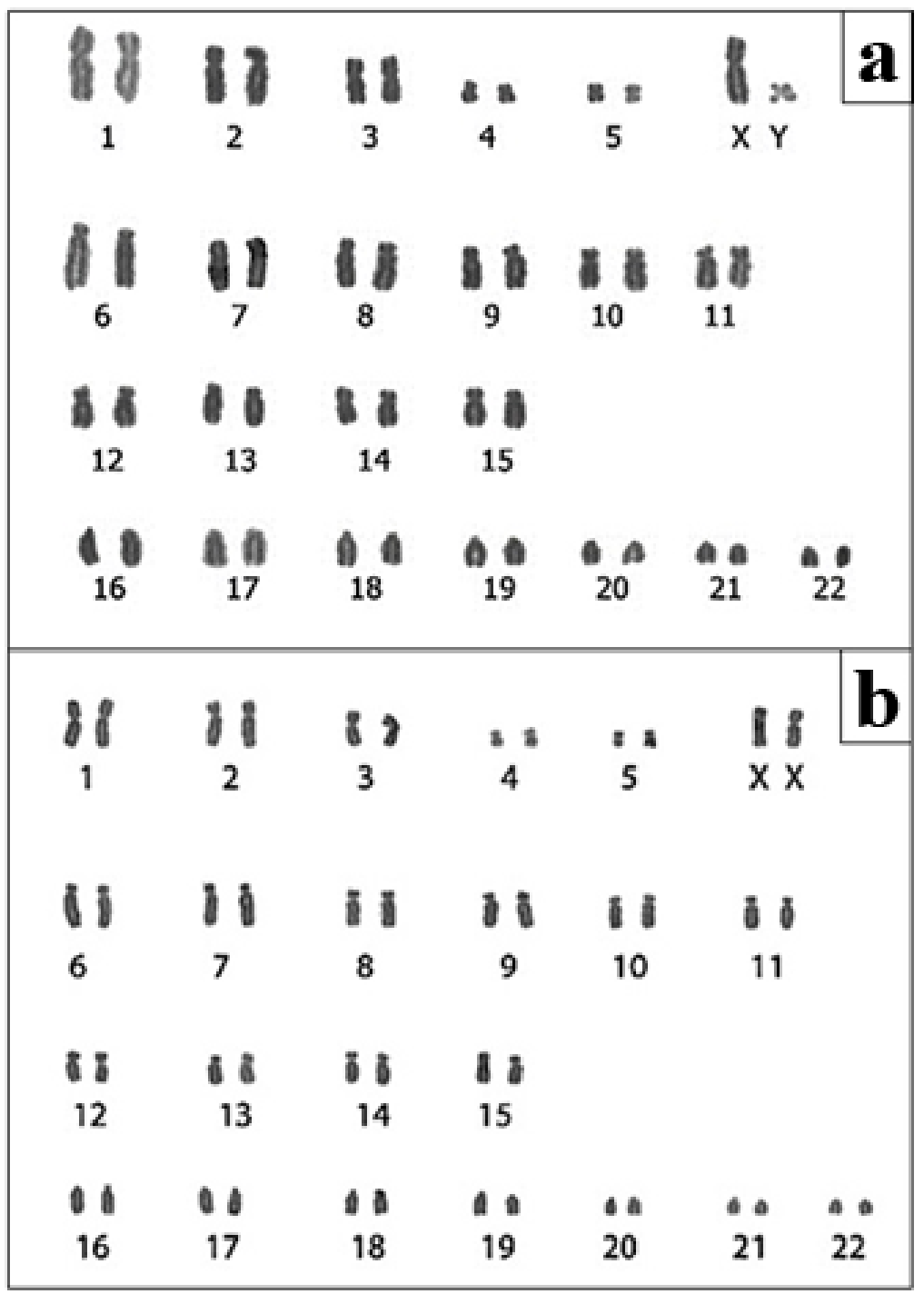

Figure 1 - Conventionally stained karyotype of a male Callithrix sp. with hematopoietic chimerism, evidencing the two cell lines (a and b) $2 \mathrm{n}=$ 46,XX[5]/46, XY[25]. [ ] Number of metaphases found for each cell lineage.

Rio de Janeiro, Brazil, by means of the cytogenetic analyzes and molecular amplification of the $S R Y$ gene by PCR. The PCR technique made it possible to detect the presence of the $S R Y$ gene in a larger number of females compared to cytogenetic analyzes.

Through cytogenetic analyzes, it was possible to identify chimerism in $13.5 \%$ of Callithrix sp. sampled. The low percentage of success in cell culture by this technique may be related to the fact that the marmosets are animals weighing on average $350 \mathrm{~g}$ (Oliveira et al. 2015), which reduces the total blood volume that can be collected. In addition, considering that obtaining metaphase chromosomes depends on approximately $30 \%$ of circulating nucleated white cells, the low number of metaphases analyzed in this study may have come from the small volume of blood collected from each individual also shared with molecular analyzes. 
TABLE II

Callithrix sp. (23 males and 7 females) samples where a 200 bp fragment of the $S R Y$ gene was amplified by PCR, including identification code, sex, age and site.

\begin{tabular}{|c|c|c|c|c|}
\hline Indivíduo & Sexo & Idade & Local & $\begin{array}{c}\text { Gene } \\
\text { SRY }\end{array}$ \\
\hline Csp003 & M & Adulto & $\begin{array}{l}\text { CETAS-RJ/ } \\
\text { IBAMA }\end{array}$ & + \\
\hline Csp004 & M & Juvenil & $\begin{array}{l}\text { CETAS-RJ/ } \\
\text { IBAMA }\end{array}$ & + \\
\hline Csp006 & $\mathrm{F}$ & Adulto & $\begin{array}{l}\text { CETAS-RJ/ } \\
\text { IBAMA }\end{array}$ & + \\
\hline Csp007 & M & Adulto & $\begin{array}{l}\text { CETAS-RJ/ } \\
\text { IBAMA }\end{array}$ & + \\
\hline Csp008 & M & Adulto & $\begin{array}{l}\text { CETAS-RJ/ } \\
\text { IBAMA }\end{array}$ & + \\
\hline Csp009 & M & Juvenil & $\begin{array}{l}\text { CETAS-RJ/ } \\
\text { IBAMA }\end{array}$ & + \\
\hline Csp010 & M & Adulto & JBRJ & + \\
\hline Csp011 & M & Adulto & JBRJ & + \\
\hline Csp012 & M & Adulto & JBRJ & + \\
\hline Csp013 & M & Adulto & JBRJ & + \\
\hline Csp015 & $\mathrm{F}$ & Adulto & JBRJ & + \\
\hline Csp016 & M & Juvenil & JBRJ & + \\
\hline Csp017 & F & Adulto & JBRJ & + \\
\hline Csp018 & M & Adulto & JBRJ & + \\
\hline Csp019 & M & Adulto & JBRJ & + \\
\hline Csp021 & M & Juvenil & JBRJ & + \\
\hline Csp022 & M & Adulto & JBRJ & + \\
\hline Csp024 & M & Adulto & UFRJ & + \\
\hline Csp025 & M & Adulto & UFRJ & + \\
\hline Csp028 & M & Adulto & UFRJ & + \\
\hline Csp029 & $\mathrm{F}$ & Adulto & UFRJ & + \\
\hline Csp030 & $\mathrm{F}$ & Adulto & UFRJ & + \\
\hline Csp031 & M & Adulto & UFRJ & + \\
\hline Csp033 & M & Adulto & UFRJ & + \\
\hline Csp035 & M & Adulto & UFRJ & + \\
\hline Csp036 & $\mathrm{F}$ & Adulto & UFRJ & + \\
\hline Csp037 & $\mathrm{F}$ & Adulto & UFRJ & + \\
\hline Csp039 & M & Adulto & UFRJ & + \\
\hline Csp040 & M & Adulto & JBRJ & + \\
\hline Csp041 & M & Adulto & JBRJ & + \\
\hline
\end{tabular}

Csp= Callithrix sp.; M= Male; $\mathrm{F}=$ Female; $+=$ presence $S R Y$ gene.
In molecular genetic analyzes, the amplification of 200 bp of the $S R Y$ gene by the PCR technique was successful in approximately $78 \%$ of the total sampled (23 males and 7 females). In six females (46.15\%) where the $2 n=46, X Y$ cell lineage had not been detected by cytogenetic analyzes, the PCR technique proved to be effective in demonstrating the presence of the $S R Y$ gene that is probably a consequence of the exchange of cells in these phenotypically normal individuals without sexual anomalies.

The causes of non-phenotypic alteration may be related to the existence of protection mechanisms that minimize the effects of the male twinning of the co-twin. Some of these mechanisms were assumed by French et al. (2016), which compare the reproductive and survival potential of at least one male co-twin callitrichids females with nonco-twin males and also analyzed the coding regions of genes linked to sexual differentiation. In the first case, no significant differences were observed between male and non-female co-twin females, showing that the presence of males in gestation does not alter the reproductive behavior nor influence on the survival of these females. Already in the second case, amino acid substitutions of the proteins expressed from the candidate genes have been observed to be responsible for the effects of endocrine regulation of the anti-Müllerian (AMH) hormones and steroids that are associated with sexual differentiation in mammals. These substitutions predicted in programs that assess the impact on the biological function of proteins, were mainly significant for the AMH system which, according to the authors reduce the channeling of early reproductive development toward the male phenotype.

Although there has been more success in $S R Y$ gene amplification by PCR, the use of this methodology alone is not enough to prove the occurrence of chimerism. In normal males, this gene is normally located on their Y chromosome, 
and in the females, the presence of the $S R Y$ gene may also be from translocation or unequal crossingover during Meiosis. A similar case was analyzed by Sanchez-Morgado et al. (2003), who studied a female Callithrix jacchus, with atypical external genitalia exhibiting only one opening to the urethra, without the presence of vulva or testicles. By PCR, the $S R Y$ gene were amplified and the sequencing did not reveal mutation leading the authors to diagnose as an $\mathrm{XY}$ female, probably considering the abnormalities of the external genitalia. Nevertheless, in our view, due to the presence of a normal SRY gene, it was expected that the individual presented testes instead of ovaries. However, the karyotype analyzes was not performed to ascertain whether there was only one cell line, $2 n=46, X Y$, or the chimeric line $2 n=46, X X / 46, X Y$.

A methodology developed by Wedi et al. (2016) seems to be a suitable identification of the cell line with chimerism. The authors developed probes for Fluorescent in situ hybridization (FISH) of the $\mathrm{X}$ and $\mathrm{Y}$ chromosomes of marmosets that can be used for any nucleated cell, allowing to identify precisely in which cellular types the chimerism occurs. In the absence of cells in metaphases originated from peripheral blood lymphocyte culture, interphase and metaphase cells obtained from other cultures such as the medulla, liver and spleen may be used. In addition, as a single cellbased cytological sexing technique it would not be questioned about contamination of various types of biological sample with blood, differently from other techniques that could produce false positives in relation to blood nucleated cell contamination.

Thus, we emphasize the importance of performing cytogenetic and molecular analyzes to diagnose chimerism in mammals, taking into account the limitations of both techniques and the possibility of errors in the interpretation of the result obtained only by PCR amplification of the SRY gene or based on the characteristics of the external genitalia.
The percentage of $32 \%$ of chimeric individuals detected in the present study is close to that observed by other authors in marmosets who analyzed a sample number similar to that reported here (Ardito et al. 1995, Gengozian et al. 1964) in the callitrichids. These data demonstrate that hybridization probably does not interfere with the occurrence of twin gestation, nor of chimerism. This is corroborated by the studies with Callithrix sp. (C. jacchus x C. penicillata) fertile hybrids in captivity (Coimbra-Filho and Maia 1976, CoimbraFilho et al. 1976) and free-living in hybridization zones (Hershkovitz 1975). High levels of fertility in chimeric individuals was demonstrated by Ardito et al. (1995), where females $2 n=46, X X / 46, X Y$ generated more concepts than females $2 n=46, X X$.

Although cytogenetics is the main tool to identify the two cell lineages present in cases of chimerism, the amplification of the $S R Y$ gene by PCR must be used to identify the Y chromosome mainly in females. A multidisciplinary approach using the confirmation of chimerism by cytogenetics and molecular genetics together with the clinical examination, histological analyzes of gonads, hormonal dosage, and behavioral assessment with a focus on paternal and alloparental care can provide a more comprehensive framework of the implications of chimerism in marmosets.

\section{ACKNOWLEDGMENTS}

We thank the Coordenação de Aperfeiçoamento de Pessoal de Nível Superior (CAPES) for providing a Master scholarship to Monique O.M. Silva and the Prof. Dr. Flavia Spreaficono of the Instituto de Nutrição Josué de Castro, Universidade Federal do Rio Janeiro (UFRJ) for providing blood samples from the individuals of Callithrix sp. in captivity. We also thank the undergraduate student in Biological Sciences, Jéssica Andrade, for helping in collecting and in the cytogenetic analyzes and the JBRJ Trainees for assisting in the captures. 


\section{REFERENCES}

ABBOTT DH. 1984. Differentiation of sexual behaviour in female marmoset monkeys: effects of neonatal testosterone or a male co-twin. Prog Brain Res 61: 349-358.

ALMEIDA J AND RESENDE AO. 2012. Freemartinismo em bovinos: revisão de literatura. RPCV 107(583-584): 133141.

ARDITO G, LAMBERTI L, BIGATTI E, CROVELLA S AND OBERTO G. 1995. No correlation between chimerism and fertility in Callithrix jacchus (Callithricidae, Primates). Int J Anthropol 10(1): 15-19.

ARNOLD ML AND MEYER A. 2006. Natural hybridization in primates: One evolutionary mechanism. Zoology 109: 261-276.

ASSAF SA, RANDOLPH LM, BENIRSCHKE K, WU S, SAMADI R AND CHMAIT RH. 2010. Discordant blood chimerism in dizygotic monochorionic laser-treated twintwin transfusion syndrome. Obstet Gynecol 2: 483-485.

AVILA-PIRES FD. 1969. Taxonomia e zoogeografia do gênero Callithrix (Erxleben, 1777) (Primates: Callitrichidae). Rev Brasil Biol 29: 49-64.

BENIRSCHKE K, ANDERSON JM AND BROWNHILL LE. 1962. Marrow chimerism in marmosets. Science 138: 513515.

BENIRSCHKE KAND BROWNHILLLE. 1963. Heterosexual cells in testes of chimeric marmoset monkey. Cytogenetics 2: $331-341$

CEZAR AM, PESSOA LM AND BONVICINO CR. 2017. Morphological and genetic diversity in Callithrix hybrids in an anthropogenic area in Southeastern Brazil (Primates: Cebidae: Callitrichinae). Zoologia 34: 1-9.

CHEN K, CHMAIT RH, VANDERBILT D, WU S AND RANDOLPH L. 2013. Chimerism in monochorionic

dizygotic twins: Case study and review. Am J Med Genet 161A: 1817-1824.

COIMBRA-FILHO AF. 1970. Acerca de um caso de hibridismo entre Callithirx jacchus (L., 1758) x C. geoffroy (Humboldt, 1812) (Callitrichidae, Primates). Rev Brasil Biol 30(4): 507-517.

COIMBRA-FILHO AF, ROCHA NC AND PISSINATTI A. 1976. Gestação quádrupla de triplo-híbridos em Callithrix duplo-híbrida (Callitrichidae, Primates). Rev Brasil Biol 36(3): 675-681.

COIMBRA-FILHO AF AND MAIA AA. 1976. Hibridismo de Callithrix geoffroy (Humboldt, 1812) x C. jacchus (Linneaus, 1758), e criação artificial de filhote híbrido (Callitrichidae, Primates). Rev Brasil Biol 36(3): 665-673.

DOMINGUEZ MM, LIPTRAP RM, CROY BA AND BASRUR PK. 1990. Correlates of Ovarian Alterations in Bovine Freemartin Fetuses. Anim Reprod Sci 22: 181-201.

DUNN HO, KENNEY RM AND LEIN DH. 1968. XX/XY chimerism in a bovine true hermaphrodite: an insight into the understanding of freemartinism. Cytogenetics 7: 390402.

DUNSFORD I, BOWLEY CC, HUTCHISON AM, THOMPSON JS, SANGER R AND RACE RR. 1953. A Human Blood-Group Chimera. Brit Med 2: 81.

ELDRIDGE FE AND BLAZAK WF. 1976. Chromosomal Analysis of Fertile Female Heterosexual Twins in Cattle. J Dairy Sci 60(3): 458-463.

FRENCH JA, FRYE B, CAVANAUGH J, REN D, MUSTOE AC, RAPAPORT L AND MICKELBERG J. 2016. Gene changes may minimize masculinizing and defeminizing influences of exposure to male cotwins in female callitrichine primates. Biol Sex Differ 7(28): 1-11.

GENGOZIAN N, BATSON JS AND EIDE P. 1964. Hematologic and cytogenetic evidence for hematopoietic chimerism in the marmoset, Tamarinus nigricollis. Cytogenetics 3: 384-393.

GENGOZIAN N, BATSON JS, GREENE CT AND GOSSLEE DG. 1969. Hemopoietic chimerism in imported and laboratory-bred marmosets. Transplantation 8: 633-652.

GENGOZIAN N, BREWEN JG, PRESTON RJ AND BATSON JS. 1980. Presumptive evidence for the absence of functional germ cell chimerism in the marmoset. J Med Primatol 9: 9-27.

GOLDSCHMIDT B, MORAES IA, SOUZA LM, PAULINO FS, PISSINATTI A, MÁRSICO FF, FERREIRA AMR AND PINHO TG. 2005. Occurrence of virilization signals in a female marmoset Leontopithecus chrysomelas (Callithrichidae, Primates) with 46,XX/46,XY chimerism. Isr J Vet Med 60(3): 86-88.

GRAVES JM. 1998. Evolution of the Mammalian Y Chromosome and Sex-Determining Genes. J Exp Zool 281: 472-481.

HAIG D. 1999. What is a marmosets? Am J Primatol 49: $285-$ 296.

HERSCHLER MS AND FECHHEIMER NS. 1967. The Role of Sex Chromosome Chimerism in Altering Sexual Development of Mammals. Cytogenetics 6: 204-212.

HERSHKOVITZ P. 1975. Comments on the Taxonomy of Brazilian Marmosets (Callithrix, Callithrichidae). Folia primatol 24: 137-172.

HERSHKOVITZ P. 1977. Living New World monkeys (Platyrrhini) with an introduction to Primates. Vol. 1. Chicago: Chicago University Press, 1,132 p.

HILL JP. 1926. Demonstration of the Embryologia varia (development of Hapale jacchus). J Anat 60: 486-487.

JAQUISH CE, TARDIF SD, TOAL RL AND CARSON RL. 1996. Patterns of prenatal survival in the common marmoset (Callithrix jacchus). J Med Primatol 25: 57-63.

LILLIE FR. 1916. The theory of the freemartin. Science 43: 611-613. 
LILLIE FR. 1917. The freemartin: a study of the action of sex hormones in the foetal life of cattle. J Exp Zool 23: 371-452.

MALUKIEWICZ J, BOERE V, FUZESSY LF, GRATIVOL AD, DE OLIVEIRA E SILVA I, PEREIRA LCM, RUIZMIRANDA R, VALENÇA YM AND STONE AC. 2015. Natural and Anthropogenic Hybridization in Two Species of Eastern Brazilian Marmosets (Callithrix jacchus and $C$. penicillata). PLoS ONE 10(6): 1-22.

MCFEELY RA, HARE WCD AND BIGGERS JD. 1967. Chromosome Studies in 14 Cases of Intersex in Domestic Mammals. Cytogenetics 6: 242-253.

MEYERS-WALLEN VN. 2012. Gonadal and Sex Differentiation Abnormalities of Dogs and Cats. Sex Dev 6: 46-60.

MILLER SA, DYKES DD AND POLESKY HF. 1988. A simple salting out procedure for extracting DNA from human nucleated cells. Nucleic Acids Res 16: 1215.

MIRANDA RIBEIRO A. 1912. Dois novos simios da nossa fauna. Brasil. Rundschau 2(1): 21-23.

MITTERMEIER RA, RYLANDS AB AND COIMBRAFILHO AF. 1988. Systematics: species and subspecies - an update. In: Mittermeier RA, Rylands AB, Coimbra- Filho AF and da Fonseca GAB (Eds), p. 13-75.

MOORE HDM, GEMS S AND HEARN JP. 1985. Early Implantation stages in the marmoset monkey (Callithrix jacchus). Am J Anat 172: 265-278.

MOORHEAD PS, NORWELL PC, MELLMAN WJ, BATTIPS DM AND HUNGERFORD DA. 1960. Chromosome Preparations of Leukocytes Cultured from Human Peripheral Blood. Exp Cell Res 20: 613-615.

MOREIRA MA. 2002. SRY evolution in Cebidae (Platyrrhini: Primates). J Mol Evol 55: 92-103.

MULLIS KB AND FALOONA EA. 1986. Specific synthesis of DNA in vitro via a polymerase-catalyzed chain reaction. Meth Enzymol 155: 335-350.

NAGAMACHI CY, PIECZARKA JC, SCHWARZ M, BARROS RMS AND MATTEVI MS. 1997. Comparative chromosomal study of five taxa of genus Callithrix, group jacchus (Platyrrhini, Primates). Am J Primatol 41: 53-60.

NICHOLAS JW, JENKINS WJ AND MARSH WL. 1957. Human Blood Chimeras A study of surviving twins. Brit Med J 1: 1458-1460.

NOGUEIRA DM, FERREIRA AMR, GOLDSCHMIDT B, PISSINATTI A, CARELLI JB AND VERONA CE. 2011. Cytogenetic study in natural hybrids of Callithrix (Callitrichidae: Primates) in the Atlantic forest of the State of Rio de Janeiro, Brazil. Iheringia 101(3): 156-160.

OHNO S, TRUJILLO JM, STENIUS C, CHRISTIAN LC AND TEPLITZ RL. 1962. Possible Germ Cell Chimeras Among Newborn Dizygotic Twin Calves (Bos taurus). Cytogenetics 1: 258-265.
OLIVEIRA AMD, NOGUEIRA DM, FERREIRA AMDR, PISSINATTI A AND CARVALHO EFD. 2010. SRY Gene Polymorphism: A Tool To Evaluate Natural Hybridization In South American Primates. Haploid DNA markers in forensic genetics, $64 \mathrm{p}$.

OLIVEIRA GR, AMORA TD, REIS NL, PERACCHI AL AND ROSA GLM. 2015. Gênero Callithrix (Erxleben, 1777). Primatas do Brasil: guia de campo. In: Reis NR, Peracchi AL, Batista CB and Rosa GLM (Eds), p. 64-77.

OWEN RD. 1945. Immunogenetic consequences of vascular anastomoses between bovine twins. Science 102: 400-401.

PADULA AM. 2005. The freemartin syndrome: an update. Anim Reprod Sci 87: 93-109.

REDLINE RW. 2003. Nonidentical twins with a single placenta-disproving dogma in perinatal pathology. N Engl J Med 349: 111-114.

REIS NR, PERACCHI AL, BATISTA CB AND ROSA GLM. 2015. Primatas do Brasil: Guia de campo. Rio de Janeiro: Technical Books, $328 \mathrm{p}$.

ROSS CN, FRENCH JA AND ORTI G. 2007. Germ-line chimerism and paternal care in marmosets (Callithrix kuhlii). PNAS 104(15): 6278-6282.

RYLANDS AB. 1993. Marmosets and Tamarins: Systematics, Behaviour, and Ecology. Oxford: Oxford University Press, 396 p.

RYLANDS AB, SCHNEIDER H, LANGGUTH A, MITTERMEIER RA, GROVES CP AND RODRIGUEZLUNA E. 2000. An assessment of the diversity of new world primatas. Neotrop Primates 8: 61-93.

SANCHEZ-MORGADO JM, HAWORTH R AND MORRIS TH. 2003. XY female marmoset (Callithrix jacchus). Comp Med 53: 539-544.

SANTOS CV AND MARTINS MM. 2000. Parental care in the buffy-tufted-ear marmoset (Callithrix aurita) in wild and captive groups. Rev Brasil Biol 60(4): 667-672.

SINCLAIR AH, BERTA P, PALMER MS, HAWKINS JR, GRIFFTHS BL, SMITH MJ, FOSTER JW, FRISCHAUF AM, LOVELL-BADGE R AND GOODFELLOW PN. 1990. A gene from the human sex-determinning region encodes a protein with homology to a conserved DNAbinding motif. Nature 346: 240-244.

SWEENEY CG, WARD JM AND VALLENDER EJ. 2012. Naturally occurring, physiologically normal, primate chimeras. Landes Bioscience Chimerism 3(2): 43-44.

TAKABAYASHI S AND KATOH H. 2011. Sex Identification Using the $Z F X$ and $Z F Y$ Genes in Common Marmosets (Callithrix jacchus). Exp Anim 60(4): 417-420.

TARDIF SD, RICHTER CB AND CARSON RL. 1984. Reproductive performance of three species of Callitrichidae. J Am Assoc Lab Anim Sci 34(3): 272-275.

TARKOWSKI AK. 1970. Germ cells in natural and experimental chimaeras in mammals. Phil Trans R Soc Lond B 259: 107-111. 
VAN ROOSMALEN MGM AND VAN ROOSMALEN T. 2003. The description of a new marmoset genus, Callibella (Callitrichinae, Primates), including its molecular phylogenetic status. Neotrop Primates 11(1): 1-10.

VIEIRA CC. 1955. Lista remissiva dos mamíferos do Brasil. Archoos Zool Est S Paulo 8: 341-474.

WARD JM, BUSLOV AM AND VALLENDER EJ. 2014. Twinning and Survivorship of Captive Common Marmosets (Callithrix jacchus) and Cotton-Top Tamarins (Saguinus oedipus). J Am Assoc Lab Anim Sci 53(1): 7-11. WEDI E, MÜLLER S, NEUSSER M, VOGTC PH, TKACHENKO OY, ZIMMER CJ, SMEETS D, MICHELMANN GHW AND NAYUDU APL. 2016. Detection of cross-sex chimerism in the common marmoset monkey (Callithrix jacchus) in interphase cells using fluorescence in situ hybridisation probes specific for the marmoset $\mathrm{X}$ and $\mathrm{Y}$ chromosomes. Reprod Fertil Dev 29(5): 913-920.

WEDI E, NAYUDU PL AND MICHELMANN HW. 2011. A case report of spontaneous opening of congenitally fused labia in a female common marmoset (Callithrix jacchus) followed by pregnancy and birth of twins. J Med Primatol 40: 351-353.

WISLOCKI GB. 1932. Placentation in the marmoset (Oedipomidas geoffroyi) with remarks on twinning in monkeys. Anat Rec 52: 381-399.

WISLOCKI GB. 1939. Observations on twinning marmosets. Am J Anat 64: 445-483.

WORLEY KC ET AL. 2014. The common marmoset genome provides insight into primate biology and evolution. Marmoset Genome Sequencing and Analysis Consortium. Nat Genet 46(8): 850-857. 